\title{
PENANGKARAN PADI DALAM UPAYA PEMENUHAN BENIH MANDIRI PADA KELOMPOK TANI AIR SARASAH DI NAGARI SUNGAI BATANG KECAMATAN TANJUNG RAYA KABUPATEN AGAM
}

\author{
Irfan Suliansyah*), Fitri Ekawati, Doni Hariandi, Obel, Nugraha Ramadhan, \\ Rachmad Hersi Martinsyah,Winda Purnama Sari, dan Sanna Paija Hasibuan
}

\author{
Program Studi Agroteknologi Fakultas Pertanian Universitas Andalas \\ *)Email: irfansuliansyah@agr.unand.ac.id
}

\begin{abstract}
ABSTRAK
Salah satu faktor rendahnya produktivitas padi di Provinsi Sumatera Barat adalah masih kurangnya penggunaan benih yang berkualitas. Di samping itu, varietas padi yang digunakan pada saat ini memiliki resistensi yang rendah terhadap hama dan penyakit, khususnya hama wereng yang dewasa ini sering menyerang padi di Sumatera Barat. Badan Tenaga Nuklir Nasional (BATAN) merupakan salah satu institusi yang menghasilkan varietas padi baru melalui teknologi mutasi, salah satu varietas yang dihasilkan adalah varietas Kahayan. Varietas Kahayan memiliki beberapa keunggulan dibandingkan varietas sebelumnya, yaitu berumur genjah, produktivitas tinggi, serta memiliki resistensi terhadap beberapa hama dan penyakit tanaman tertentu. Tujuan kegiatan ini adalah melakukan diseminasi penangkaran benih padi varietas Kahayan kepada kelompok tani penangkar agar mereka dapat memenuhi kebutuhan benih padinya secara mandiri. Kegiatan dilaksanakan pada Kelompok Tani Air Sarasah di Nagari Sungai Batang, Kecamatan Tanjung Raya, Kabupaten Agam pada November 2019 hingga Maret 2020. Kegiatan terdiri atas sosialisasi kegiatan penangkaran, pelaksanaan penangkaran padi varietas Kahayan, dan pendampingan penangkaran padi varietas Kahayan. Dari kegiatan ini kelompok tani mampu telah melakukan penangkaran padi dengan lebih baik, sesuai dengan standar operasional penangkaran benih yang telah ditetapkan oleh Kementerian Pertanian Republik Indonesia. Di samping itu, kelompok tani juga telah mampu meningkatkan pengetahuan mereka dalam melakukan sertifikasi benih padi. Dari hasil penangkaran diperoleh hasil benih padi Kahayan kelas Benih Dasar (BD) sebanyak 6,1 ton/hektar yang melebihi hasil rata-rata padi nasional, yaitu pada tahun 2018 sebanyak 5,2 ton/hektar.
\end{abstract}

Kata Kunci: benih, diseminasi, kahayan, penangkaran

\section{Breeding of Rice in Efforts of Fulfilling Rice Seeds in Air Sarasah Farmer Group in Nagari Sungai Batang, Tanjung Raya District, Agam Regency}

\begin{abstract}
One of the factors causing the low productivity of rice in West Sumatra Province is quality seeds, which are still very low. Also, many rice varieties currently used have a low resistance to pests and diseases, particularly the leafhoppers, which currently attack rice in West Sumatra. The National Nuclear Energy Agency (BATAN) is one of the institutions that produce new rice varieties through mutation technology, one of the varieties produced in the Kahayan variety. Kahayan varieties have several advantages over the previous varieties, namely early age, high productivity, and resistance to certain pests and plant diseases. This activity aims to disseminate the breeding of Kahayan rice seeds to breeding farmer groups so that they can fulfill their needs for rice seeds independently. The activity was carried out at the Air Sarasah Farmer Group in Nagari Sungai Batang, Tanjung Raya District, Agam Regency, from November 2019 to March 2020. The activity consisted of disseminating breeding activities, implementing Kahayan rice breeding, and assisting Kahayan rice varieties' breeding. From this activity, farmer groups have been able to better breed rice, according to the operational standards for seed breeding set by the Ministry of Agriculture of the Republic of Indonesia. Also, farmer groups have
\end{abstract}


been able to increase their knowledge of certifying rice seeds. From the results of rice seed breeding, it was obtained that the Kahayan rice seed class Basic Seed (BD) yield was 6.1 tonnes/hectare, which exceeded the national average rice yield, namely in 2018, it was 5.2 tonnes/hectare.

Keywords: breeding, dissemination, kahayan, seed

\section{PENDAHULUAN}

Beras hingga saat ini masih menjadi pangan sumber karbohidrat utama masyarakat Indonesia dengan partisipasi konsumsi hampir mencapai 100\%, yang berarti hampir semua rumah tangga mengkonsumsi beras. Termasuk di Sumatera Barat yang konsumsi beras per kapitanya tertinggi dibandingkan provinsi lainnya di Indonesia, yaitu mencapai $102,5 \mathrm{~kg}$ per kapita per tahun dibandingkan konsumsi beras Indonesia pada tahun 2019 adalah 96,3 kg per kapita per tahun (Wijayati, Harianto, Suryana, 2019).

Luas areal penanaman padi di Provinsi Sumatera Barat tahun 2019 adalah 311.671,23 hektar dengan produksi 1.482.996,01 ton atau setara dengan tingkat produktivitas 4,8 ton per hektar (BPS Provinsi Sumbar, 2020). Produktivitas ini masih di bawah produktivitas nasional yang telah mencapai 5,1 ton gabah kering giling per hektarnya (BPS, 2019). Pemerintah pusat menargetkan produksi padi di Provinsi Sumatera Barat dapat mencapai tiga juta ton, namun hingga saat ini masih belum dapat terealisasi (Faisal, 2018).

Berdasarkan informasi yang berasal dari Kepala Dinas Tanaman Pangan, Hortikultura dan Perkebunan Sumatera Barat, pencapaian target produksi padi di provinsi Sumatera Barat terkendala tidak optimalnya fungsi irigasi sawah serta ketersediaan benih padi yang berkualitas (Faisal, 2018; Mislaini dan Fahmy, 2018).

Benih padi berkualitas sangat ditentukan oleh genetika dari padi tersebut. Padi varietas baru umumnya di desain memiliki karakteristik yang lebih baik dibandingkan genotipe lokalnya. Petani Sumatera Barat umumnya masih menanam padi lokal, karena memiliki karakter tekstur nasi yang disukai masyarakat Sumatera Barat, yaitu bertekstur pera. Perbaikan padi di Indonesia umumnya hanya memperbaiki padi-padi yang bertekstur pulen. Sehingga padi-padi baru tersebut tidak bisa didistribusikan dan ditanam di Sumatera Barat.

Padi lokal di Sumatera Barat yang banyak dibudidayakan petani pada umumnya memiliki karakteristik berumur panjang, memiliki idiotipe yang tinggi, serta resistensi yang rendah terhadap hama dan penyakit (Nurnayetti dan Atman, 2013). Baru-baru ini banyak petani di Sumatera Barat yang mengeluh setelah tanamannya terserang hama wereng. Serangan hama tersebut banyak mengakibatkan kegagalan panen. Mereka meminta kepada aparat pemerintah agar disediakan padi jenis baru yang lebih tahan tehadap serangan hama wereng (Mahmud, 2020).

Salah satu institusi yang berperan dalam pengembangan padi nasional adalah Badan Tenaga Nuklir Nasional (BATAN). Telah banyak varietas padi hasil penelitian Tim BATAN yang sudah dirilis dan dimanfaatkan oleh petani (BATAN, 2017). Salah satu padi yang dihasilkan BATAN adalah varietas Kahayan. Varietas Kahayan memiliki tekstur yang agak pera, sehingga akan dapat diterima oleh masyarakat Sumatera Barat. Disamping itu, kelebihan varietas Kahayan adalah memiliki umur yang genjah, idiotipe sedang, serta 
memiliki resistensi yang baik terhadap hama wereng.

Varietas Kahayan merupakan varietas baru di Provinsi Sumatera Barat. Oleh karena itu, perlu upaya pengenalan (diseminasi) varietas tersebut ke petani-petani di Sumatera Barat. Diseminasi suatu varietas tanaman yang baru memerlukan beberapa tahapan kegiatan, salah satunya adalah kegiatan perbanyakan benihnya (penangkaran). Kegiatan penangkaran harus dilaksanakan secara hati-hati, karena hal ini menyangkut dengan kemurnian benih yang akan didistribusikan dan dibudidayakan oleh petani. Agar kegiatan penangkaran dapat memenuhi sasaran yang dikehendaki, maka perlu adanya kerja sama beberapa institusi. Oleh karena itu kegiatan penangkaran ini melibatkan tiga stakeholders, yaitu BATAN sebagai pemilik dari varietas Kahayan dengan tugas menyediakan benih BS (Breeder Seed). Dinas pertanian setempat yang mewakili kelompok tani penangkar. Bertindak sebagai mediator antara BATAN dan penangkar adalah Tim yang berasal dari Fakultas Pertanian Universitas Andalas. Pemilihan Kelompok Tani Air Sarasah sebagai mitra dalam penangkaran benih padi Kahayan karena anggota kelompok tani ini seluruhnya merupakan petani padi yang membutuhkan benih berkualitas setiap musim tanamannya. Di samping itu, lokasi penangkaran terletak strategis di antara beberapa kelompok tani lain yang juga membudidayakan padi. Sehingga sosialisasi dan pendistribusian benihnya dapat lebih mudah.

Tujuan kegiatan ini adalah melakukan diseminasi penangkaran benih padi varietas Kahayan kepada kelompok tani penangkar agar mereka dapat memenuhi kebutuhan benih padinya secara mandiri serta secara kontinyu dapat terus memproduksi benih padi.

\section{METODE}

\section{a. Waktu dan Tempat}

Pelaksanaan kegiatan penangkaran dimulai pada bulan November 2019 hingga Maret 2020. Kegiatan dilaksanakan di lahan sawah irigasi Kelompok Tani Air Sarasah yang berlokasi di Jorong Labuah, Nagari Sungai Batang, Kecamatan Tanjung Raya, Kabupaten Agam, Sumatera Barat.

\section{b. Metodologi}

Kegiatan terdiri atas: 1) sosialisasi kegiatan penangkaran, 2) penangkaran padi varietas Kahayan, dan 3) pendampingan penangkaran padi varietas Kahayan. Luas area penangkaran adalah 1 (satu) hektar. Pada kegiatan penangkaran ini juga melibatkan petugas dari Dinas Pertanian Kabupaten Agam, yaitu Koordinator Balai Penyuluhan Pertanian (BPP) dan Petugas Pengendali Organisme Pengganggu Tanaman (POPT) Kecamatan Tanjung Raya, sebagai pihak yang akan membantu dalam pengelolaan kegiatan penangkaran hingga pengurusan sertifikasi benih.

Sosialisasi kegiatan penangkaran dilakukan dengan mengumpulkan anggota kelompok tani dan stake holders yang terkait. Sosialisasi dilakukan dengan memberikan penjelasan secara interaktif serta berdiskusi langsung tentang rencana kegiatan penangkaran yang akan dilaksanakan.

Teknologi budidaya padi untuk penangkaran ini disesuaikan dengan teknologi budidaya padi setempat, yaitu terdiri atas persemaian, penanaman (transplanting), 
pemeliharaan, dan panen. Persemaian dilakukan melalui persemaian basah, dengan cara merendam benih semalam, selanjutnya disebar/ditanam di sebagian lahan sawah petani. Setelah benih/bibit berumur 16 hari, maka bibit telah siap untuk ditanam di lahan sawah (transplanting). Tata cara perawatan untuk penangkaran padi disesuaikan dengan tata cara setempat, baik pengendalian gulma, pemupukan, pengendalian hama dan penyakit, serta pengaturan air irigasi. Namun, harus tetap mengacu pada Standar Operasional dan Prosedur untuk penangkaran benih yang sudah ditetapkan oleh Balai Pengawasan dan Sertifikasi (BPSB) Provinsi Sumatera Barat.

Kegiatan penangkaran dilaksanakan dalam rangka menyediakan benih unggul yang berkualitas secara kontinyu. Benih yang ditangkarkan untuk tahap pertama adalah benih padi BP (Benih Penjenis/Breeder Seed) yang dihasilkan oleh Pusat Aplikasi Isotop dan Radiasi (PAIR) - BATAN. Dari hasil penangkaran ini diharapkan akan diperoleh dan tersertifikasi benih BD (Benih Dasar/Foundation Seed). Selanjutnya benih BD ditangkarkan kembali untuk memperoleh benih BP (Benih Pokok - Stock Seed). Terakhir benih BP ditangkarkan kembali untuk memperoleh benih BR (Benih Sebar - Extension Seed). Benih sebar inilah selanjutnya yang dapat digunakan oleh para petani untuk melakukan budidaya tanaman padinya.

\section{HASIL DAN PEMBAHASAN}

\section{a. Sosialisasi Kegiatan Penangkaran}

Kegiatan penangkaran diawali dengan melakukan sosialisasi kepada kelompok tani. Sosialisasi dilakukan dengan cara melakukan pertemuan dengan pengurus dan seluruh anggota kelompok tani. Pertemuan juga dihadiri oleh petugas dari Dinas Pertanian Kabupaten Agam, yaitu Tawari Hayati, SP sebagai Koordinator Balai Penyuluhan Pertanian (BPP) dan Yasril, SP sebagai Petugas Pengendali Organisme Pengganggu Tanaman (POPT) Kecamatan Tanjung Raya Kabupaten Agam. Ikut serta berpartisipasi dalam pertemuan tersebut adalah Wali Nagari Kenagarian Sungai Batang Kecamatan Tanjung Raya. Dokumentasi kegiatan sosialisasi dapat dilihat pada Gambar 1.

Benih bermutu (bersetifikasi) mempunyai kelebihan dibanding dengan benih tidak bermutu. Adapun kelebihan dari benih bermutu yaitu mengurangi resiko kegagalan budidaya karena benih mampu tumbuh baik pada kondisi lahan yang kurang menguntungkan, produksinya lebih tinggi, dan tahan terhadap serangan hama dan penyakit. Meskipun benih tidak bermutu mudah di dapat dan mempunyai harga yang murah, tapi memiliki beberapa kekurangan antara lain kemurnian dari suatu tanaman mengalami kemunduran, pertumbuhan dan umur tanaman tidak sama dalam suatu varietas, hasil dan mutunya semakin menurun sebab kematangan dari suatu gabah berlainan, serta semakin lama bentuk tanaman semakin menyimpang dari bentuk tanaman pokok (Wirawan dan Wahyuni, 2002).

Peranan benih dalam usaha peningkatan produksi dan kualitas sangat besar. Penyediaan benih dalam masa pembangunan pertanian merupakan faktor yang menentukan berhasil atau tidaknya usaha pertanian ini. Sehubungan dengan kenyataan ini pemerintah telah merencanakan untuk mengintensifikasi usaha rehalibitasi kebun bibit untuk dapat meningkatkan produksi bibit atau benih yang bermutu, di samping 
usaha bimbingan dan pengawasan terhadap pembibitan swasta (Kartasapoetra, 2003).
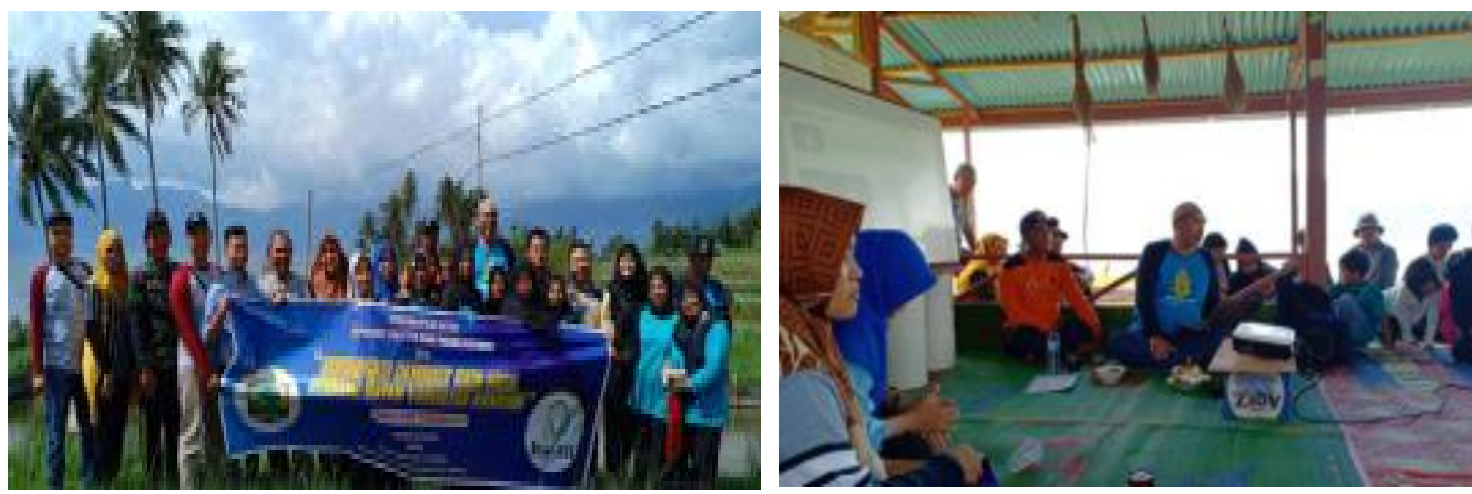

Gambar 1. Sosialisasi Kegiatan Penangkaran Padi Varietas Kahayan

Kegiatan diisi dengan pemaparan tentang pentingnya penggunaan benih unggul dalam budidaya tanaman secara umum dan dilanjutkan dengan pemaparan tentang benih padi varietas Kahayan. Pada kesempatan ini Wali Nagari juga menyampaikan kepada kelompok tani agar dapat memanfaatkan kerja sama ini untuk meningkatkan produktivitas tanaman padi mereka serta mampu menyediakan kebutuhan benih padinya secara mandiri serta berkesinambungan. Kegiatan sosialisasi diakhiri dengan tanya jawab bersama anggota kelompok tani.

\section{b. Penangkaran Padi Varietas Kahayan}

Penangkaran Padi Hasil Litbang BATAN varietas Kahayan telah dilaksanakan di lahan sawah irigasi Kelompok Tani Air Sarasah di Jorong Labuah, Nagari Sungai Batang, Kecamatan Tanjung Raya, Kabupaten Agam. Kegiatan penangkaran padi diawasi dan disupervisi secara reguler oleh petugas dari Dinas Pertanian Kabupaten Agam.

Status kegiatan penangkaran benih padi varietas Kahayan dari kelas BP (Benih Penjenis) menjadi kelas BD (Benih Dasar) seluruhnya telah selesai dilaksanakan. Kegiatan tahap awal dalam penangkaran benih adalah melakukan persemaian benih untuk menghasilkan bibit yang akan ditanam di lahan sawah. Kegiatan persemaian benih terdiri atas: persiapan benih, penyiapan lahan untuk pembenihan, penanaman benih, dan perawatan benih (bibit). Selanjutnya setelah berumur 16 hari bibit telah siap dipindahkan ke lahan sawah. Dokumentasi kegiatan perbenihan dapat dilihat pada Gambar 2.

Kegiatan selanjutnya adalah penanaman bibit ke lahan sawah. Bibit padi dicabut secara manual dan hati-hati selanjutnya ditanam masing-masing lubang tanam sekitar 4-5 bibit. Penanaman bibit antar lubang tanam dilakukan dengan menggunakan sistem tegel dengan jarak tanam $25 \mathrm{~cm}$ x $25 \mathrm{~cm}$. Bibit selanjutnya dibiarkan dulu hingga tampak adanya gejala bibit telah tumbuh. Setelah itu baru dilakukan tindakan perawatan bibit awal, yaitu pemupukan.

Berdasarkan rekomendasi pemupukan tanaman padi spesifik lokasi di Kabupaten Agam diperlukan pupuk sebagai berikut: $150 \mathrm{~kg}$ Urea, $100 \mathrm{~kg} \mathrm{SP}-36$, dan $75 \mathrm{~kg} \mathrm{KCl}$ per hektarnya (Hasan, et al., 2015). Namun, pada saat pelaksanaan, pupuk yang diberikan terdiri atas $100 \mathrm{~kg}$ Urea, $75 \mathrm{~kg}$ TSP, dan $50 \mathrm{~kg} \mathrm{KCl}$ per hektarnya. Pemupukan diberikan 
sebanyak tiga kali. Pemupukan I, yaitu pemupukan dasar diberikan pada umur 10 hari setelah tanam (HST) masing-masing: $50 \mathrm{~kg}$ Urea, $50 \mathrm{~kg}$ TSP, dan $25 \mathrm{~kg} \mathrm{KCl}$. Pemupukan II diberikan pada umur 30 HST masing-masing: $25 \mathrm{~kg}$ Urea dan $25 \mathrm{~kg}$ TSP. Pemupukan III diberikan pada umur $45 \mathrm{HST}$, yaitu $50 \mathrm{~kg} \mathrm{KCl}$. Di samping itu, menjelang padi masak penuh diberikan tambahan pupuk cair alamiah yang mengandung daun titonia yang dicampur dengan MOL (Mikro Organisme Lokal) buah-buahan.
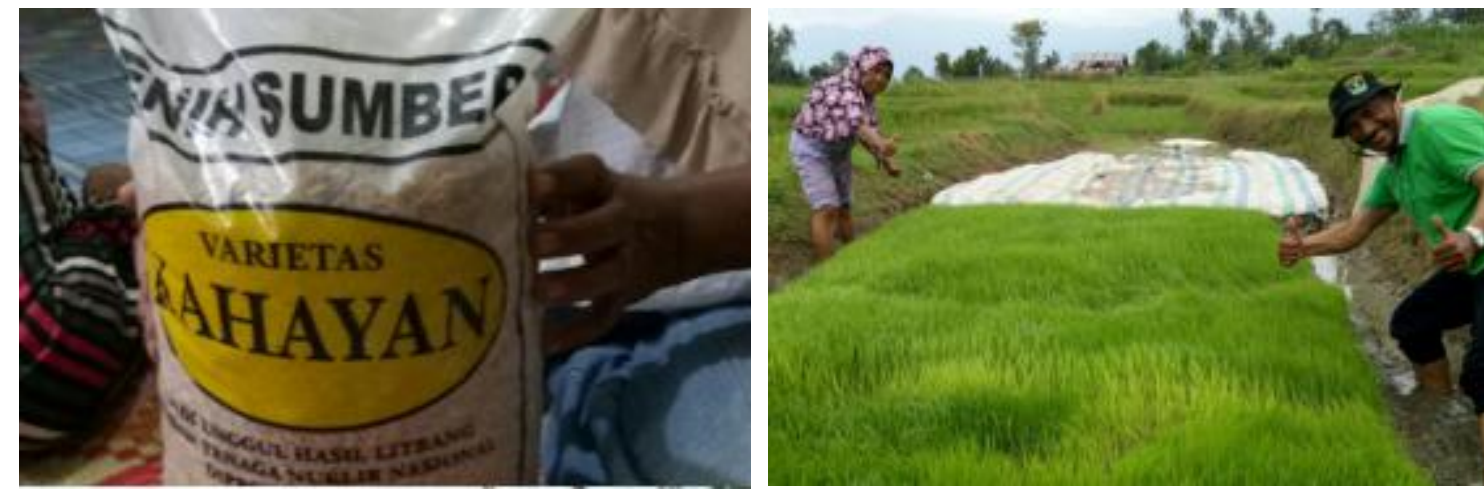

Gambar 2. Kegiatan Persemaian Benih Padi Varietas Kahayan

Perawatan tanaman padi lainnya meliputi pengaturan air irigasi, dimana air diatur agar sawah tetap tergenangi pada saat pertumbuhan vegetatif hingga awal perkembangan generatif. Pada masa akhir generatif, pengairan dikurangi bahkan dihentikan sama sekali pada seminggu sebelum panen. Hal ini terutama ditujukan agar memudahkan pada waktu proses pemanenan.

Pengendalian terhadap tumbuhan pengganggu (gulma) dilakukan secara manual, yaitu dengan mencabut gulma-gulma tersebut. Pengendalian gulma (penyiangan) dilakukan sebanyak dua kali, yaitu pada saat tanaman berumur 30 dan 45 hari setelah tanam. Setelah itu tidak diperlukan penyiangan lagi, karena tanaman padi sudah mulai rapat, sehingga pertumbuhan gulma sudah dapat tertekan.

Pengendalian terhadap hama dan penyakit dilakukan dengan menggunakan pestisida. Namun penggunaannya hanya bersifat kuratif, yaitu jika ada gejala penyakit atau ada sejumlah hama yang sudah mulai mengganggu tanaman, maka dilakukan penyemprotan. Secara umum tidak ada gejala serangan, baik hama atau penyakit yang berarti. Namun demikian, pada akhir pemeliharaan atau menjelang panen, sebagian tanaman diserang oleh hama tikus dan hama burung pipit. Untuk permasalahan hama burung pipit sudah di perkenalkan Teknologi Terapan Penghalau Burung Otomatis seperti yang telah dikembangkan oleh Lina, Zaini, dan Puspita (2018). Sedangkan untuk tikus, selain disarankan untuk penanaman serentak, juga disarankan untuk membasmi tikus secara berkelompok serta sanitasi di lingkungan persawahan. Dokumentasi kegiatan penangkaran dapat dilihat pada Gambar 3.

Pemanenan dilakukan setelah tanaman padi berumur 94 hari setelah tanam. Sebelum pemanen dilakukan sampel untuk mengambil data produksi ubinan pada beberapa lokasi secara acak. Dari hasil ubinan diperoleh hasil rata-rata 6,1 ton gabah per hektar. Hasil panenan selanjutnya dipersiapkan untuk penanaman berikutnya. Hasil padi yang 
diperoleh telah melebihi hasil rata-rata padi di Propisnsi Sumatera Barat, yaitu 4,8 ton per hektar (BPS Provinsi Sumbar, 2020) serta melebihi rata-rata produktivitas padi nasional yang telah mencapai 5,1 ton gabah kering giling per hektarnya (BPS, 2019). Dokumentasi panen dapat dilihat pada Gambar 4.

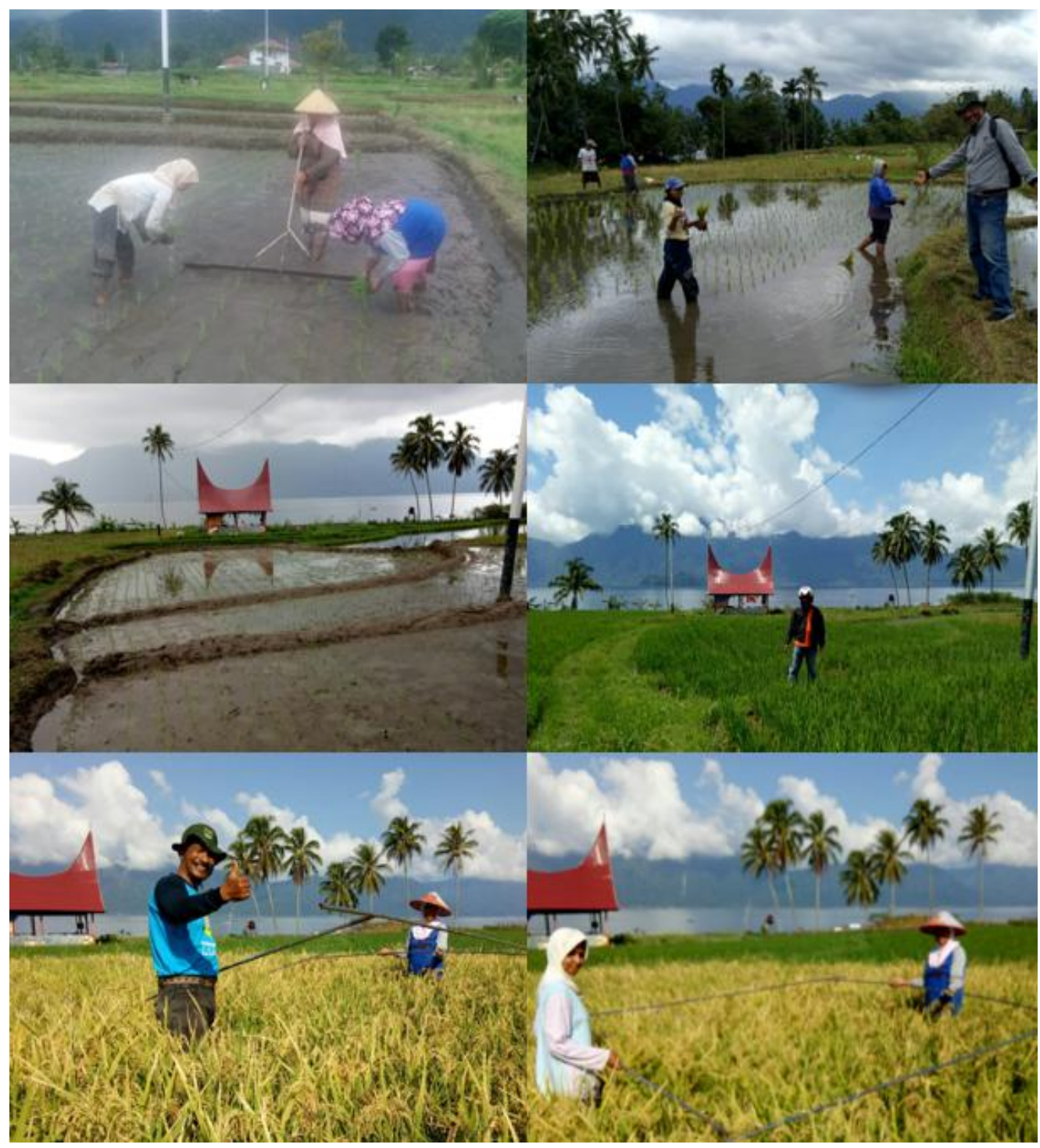

Gambar 3. Penanaman hingga Panen Kegiatan Penangkaran Benih Padi Varietas Kahayan

\section{c. Pendampingan Penangkaran Padi}

Kegiatan penangkaran padi dilakukan sebagai salah satu upaya untuk menyediakan benih padi bersertifikat varietas unggul untuk keperluan petani di daerah penangkaran padi dilaksanakan. Benih yang ditangkarkan adalah varietas Kahayan dengan kelas benih BS yang dihasilkan oleh Puslitbang Teknologi Isotop dan Radiasi - BATAN. Sebagian benih yang diperoleh dari kegiatan ini digunakan untuk penangkaran benih berikutnya, sehingga terbentuk sistem penangkaran benih yang berkelanjutan di daerah 
Sumatera Barat. Sebagian benih lainnya digunakan untuk kegiatan penyebaran benih turunan BS, demfarm, dan untuk memenuhi kebutuhan masyarakat.

Agar pelaksanaan penangkaran dapat secara kontinyu dilakukan, maka perlu adanya pendampingan dari pihak-pihak terkait, khususnya dari Dinas Pertanian setempat. Pendampingan dimaksudkan agar ada kontrol kualitas dari benih yang dihasilkan. Sehingga pada akhirnya benih padi yang didistribusikan kepada masyarakat memiliki kualitas yang dapat dipertanggungjawabkan.
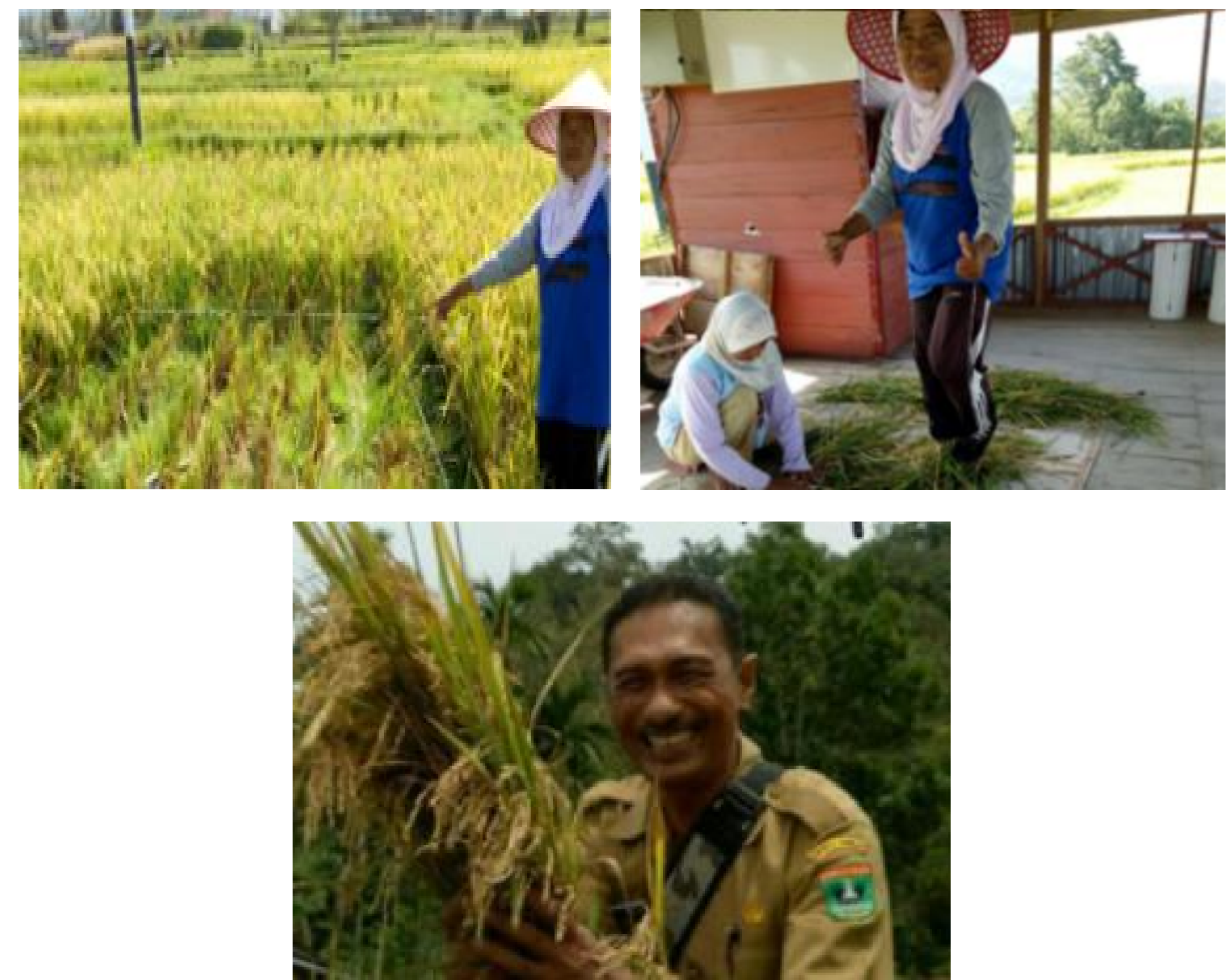

Gambar 4. Penanaman hingga Panen Kegiatan Penangkaran Benih Padi Varietas Kahayan

\section{KESIMPULAN DAN SARAN}

Kegiatan penangkaran benih padi varietas Kahayan sudah dilaksanakan di Kelompok Tani Air Sarasah yang berlokasi di Jorong Labuah, Nagari Sungai Batang, Kecamatan Tanjung Raya, Kabupaten Agam, Sumatera Barat. Kegiatan yang telah dilaksanakan terdiri atas sosialisasi kegiatan penangkaran, penangkaran padi varietas Kahayan, dan pendampingan penangkaran padi varietas Kahayan. Luas area penangkaran adalah 1 (satu) hektar. Dari kegiatan ini petani memperoleh manfaat pengetahuan cara 
melakukan penangkaran benih padi yang benar sesuai SOP Kementan RI. Dengan demikian selanjutnya petani tidak perlu membeli benih padi lagi untuk kegiatan budidaya padinya, karena mereka telah mengetahui teknologi penangkaran tersebut. Dari hasil penangkaran ini juga diperoleh hasil benih padi Kahayan kelas Benih Dasar (BD) sebanyak 6,1 ton. Benih ini selanjutnya akan didistribusikan kepada anggota kelompok tani dan ke kelompok tani pembudidaya padi lainnya.

\section{UCAPAN TERIMAKASIH}

Kepada BATAN disampaikan apresiasi dan terima kasih atas kepercayaan dan kerjasama yang terjalin selama ini. Kepada berbagai pihak yang langsung atau tidak langsung terlibat dalam kegiatan ini juga disampaikan terima kasih.

\section{DAFTAR PUSTAKA}

Badan Pusat Statistik Provinsi Sumatera Barat. 2020. Provinsi Sumatera Barat Dalam Angka. BPS Provinsi Sumatera Barat. Padang.

BPS. 2019. Luas Panen, Produksi, dan Produktivitas Padi Menurut Provinsi, 2018-2019. https://www.bps.go.id/ dynamictable/2019/04/15/1608/ luas-panen - produksi - dan - produktivitas-padi - menurut - provinsi - 2018. html. Diunduh 29 Mei 2020 .

Badan Tenaga Atom Nasional (BATAN). 2017. Laporan Tahunan Badan Tenaga Nuklir Nasional. Wisnubroto, D.S. dan F. Hermana (Eds.). Biro Perencanaan BATAN. Jakarta.

Faisal, H. 2018. Sumbar Optimistis Target Produksi 3 Juta Ton Padi Terpenuhi. https://sumatra.bisnis. com / read/ 20181213/ 533/ 869185/ sumbar-optimististarget -produksi - 3 - juta - ton-padi-terpenuhi. Diunduh 29 Mei 2020.

Hasan, N., Ismon L., Hardiyanto, S. Abdullah, R. Roswita. 2015. Rekomendasi Pupuk Spesifik Lokasi Sumatera Barat Mendukung Percepatan Swasembada Padi Sawah. Kementerian Pertanian, Badan Penelitian dan Pengembangan Pertanian, Balai Pengkajian Teknologi Pertanian Sumbar. Sukarami. 42 hal.

Kartasapoetra, A.G. 2003. Teknologi Benih (Pengolahan Benih dan Tuntutan Praktikum). Rineka Cipta: Jakarta. 188 Hal.

Lina, E.C., Zaini, dan Y. Puspita. 2018. Tek-nologi Terapan Penghalau Burung Otomatis Bagi Petani Padi di Saling-ka Kampus Universitas Andalas. Jurnal Hilirisasi IPTEKS 1 (3b): 123-132. 
Mahmud, E. 2020. Hama Wereng Serang Tanaman Padi di Kuranji Kota Padang, Petani Inginkan Varietas Padi Baru. https://padang.tribunnews.com/ 2020/01/24/hama-wereng-serang-ta-naman-padi-di-kuranji-kota-padangpetani-inginkan-varietas-padi-baru. Diunduh 12 Mei 2020.

Mislaini, R. dan K. Fahmy. 2018. Pember-dayaan Masyarakat Tani Melalui Pengelolaan Sumberdaya Air Untuk Pertanian Di Nagari Saruaso Kecama-tan Tanjung Emas Kabupaten Tanah Datar. Buletin Ilmiah Nagari Mem-bangun 1(4): 164-172.

Nurnayetti dan Atman. 2013. Keunggulan Kompetitif Padi Sawah Varietas Lokal Di Sumatera Barat. Jurnal Pengkajian dan Pengembangan Teknologi Pertanian (JPPTP) Vol. 16 No. 2:102-110.

Suliansyah, I., S. Yasin, M. Busniah, M. Syahrawati, dan F. Ekawati. 2019. Diseminasi Hasil Litbang Iptek Nuklir Bidang Pertanian Di Daerah Sumatera Barat. Jurnal Hilirisasi IPTEKS 2 (4a): 338-347.

Wijayati, P. D., Harianto, A. Suryana. 2019. Permintaan Pangan Sumber Karbohidrat Di Indonesia. Analisis Kebijakan Pertanian, Vol. 17 No. 1, Juni 2019:13-26.

Wirawan, Baran, dan S. Wahyuni. 2002. Memproduksi Benih Bersertifikasi (Padi, Jagung, Kedelai, Kacang Tanah, Kacang Hijau). Penebar Swadaya: Jakarta. 120 Hal. 